\section{Prevalência do Helicobacter pylori em pacientes sintomáticos da Ilha de São Luís, Maranhão, Brasil: estudo comparativo de cinco técnicas diagnósticas}

Este estudo apresenta o resultado de pesquisa realizada no período de 23 de agosto de 1993 a 16 de outubro de 1995 em pacientes sintomáticos (com queixa digestiva alta), atendidos no ambulatório de Clínica Médica do Hospital Universitário "Presidente Dutra", da Universidade Federal do Maranhão, com o objetivo de avaliar a prevalência do Helicobacter pylori em residentes naquela ilha, bem como comparar o desempenho de cinco técnicas de diagnóstico desta infecção. A casuística constituiu-se de 141 pacientes com idade compreendida entre 15 e 18 anos, sendo 84 do sexo masculino e 93 do sexo feminino. Após critérios previamente estabelecidos, todos foram submetidos a endoscopia digestiva alta para diagnóstico endoscópico, retirada de biópsias para pesquisa da bactéria pelos seguintes testes: hidrólise rápida da uréia (urease), exame direto (esfregaço corado pela carbolfucsina), cultura, pesquisa em corte histológico corado pela hematoxilina-eosina e sorologia quantitativa por ELISA com antígeno total. Além do exame bacteriológico no corte histológico de biópsia antral, foram estudadas as alterações histopatológicas da região. Estas e as alterações endoscópicas classificaram-se de acordo com o Sistema Sydney. Para fins de avaliação da prevalência do espiralado, nesta população, considerou-se como positivo, o paciente com qualquer um dos testes com este resultado. A prevalência geral foi, portanto, de $94,0 \%$. Para as demais variáveis, tomou-se como método padrão para definir positividade para o H. pylori, a combinação dos resultados da cultura com a histologia. Foram identificados 125 pacientes positivos e 16 negativos, correspondendo a uma prevalência de $88,6 \%$. A maior concentração de positivos ocorreu na faixa dos $25 / 35$ anos, correspondendo a $37 / 125(29,6 \%)$ e a menor nos indivíduos da faixa de 55/80, 12/125 (9,6\%). Observou-se uma tendência linear de aumento

\section{Prevalence of Helicobacter pylori in symptomatics patients of the São Luís Island, Maranhão, Brazil: comparative study of five diagnostic thecnics}

This study shows the results of a research conducted during the period between August 23rd, 1993 and October 161995 at the ambulatory of the University Hospital Presidente Dutra, of the Federal University of Maranhão, Brazil. The study was undertaken with symptomatic patients suffering from severe digestive disfunctions, and had as its main objectives to evaluate the prevalence of the bacterium Helicobacter pylori among them, as well as to compare five different diagnostic techniques for this infection. A total of 141 patients ranging from 15 to 80 years of age were tested. Among these, 84 patients were male, while 93 were female. All selected patients were submitted to digestive endoscopy for endoscopic diagnosis. Biopsy samples were also collected and the bacteria tested by the following methods: Rapid Hydrolysis of Urea (Urease Test), direct microscopic examination of hematoxylineosin stained smears, culturing in synthetic media, histologic examination of histological sections prepared with the contaminated tissue and finally, quantitative serology by ELISA using total $H$. pylori antigen. Aside from the bacteriological examination of the biopsy, any histopathologic alterations observed in the histologic sections were recorded and classified according to the Sydney scale.

To determine the overall prevalence of the infection, any patient that gave a positive result for any of the above exams was scored as a positive. The overall prevalence of the infection according to this definition was $94 \%$. In other analyses, a combination of results from culturing and histology tests was used to define infection by $H$. pylori, resulting in a total of 125 positive patients, which corresponds to a prevalence of $88.6 \%$.

The highest concentration of positives was observed among individuals between 25 and 35

Recebido para publicação em 17/02/98. 
da prevalência até os 55 anos porém, à análise estatística não houve diferença significativa entre positividade e negatividade nos grupos $(p=0,356)$. Dos pacientes positivos $45 / 125$ (36\%) foram do sexo masculino e $80 / 125(96 \%)$ do sexo feminino, não havendo diferença estatisticamente significativa na distribuição da infecção pelo sexo $(p=0,275)$. Entre pacientes brancos e não brancos também não se evidenciou diferença estatisticamente significativa com relação à infecção $(p=0,305)$. O estado civil não exerceu influência significativa sobre a prevalência $(p=0943)$. Oitenta e seis/cento e vinte e cinco $(68,8 \%)$ dos pacientes positivos eram funcionários públicos porém, em comparação com as demais atividades não houve diferença estatisticamente significativa $(p=0,788)$. Epigastralgia e pirose foram as queixas mais freqüentes. $\mathrm{O}$ achado endoscópico mais comum foi gastrite com 60/125 (48,4\%) dos positivos, seguindo-se as úlceras. A análise estatística não revelou associação significativa entre a infecção por $H$. pylori e as alterações encontradas $(p=0,72)$. As gastrites crônica e crônica ativa foram os achados mais freqüentes com 43,2 e $33,6 \%$ do total de positivos e ocorreu associação estatisticamente significativa entre as alterações histopatológicas do antro e presença da bactéria $(p=0,000083)$. Os cinco métodos de diagnóstico apresentaram os seguintes índices de positividade: $82,3 \%$ (urease), $80,1 \%$ (exame direto), 69,5\% (cultura), 87,2\% (histologia) e $86,5 \%$ (sorologia) porém, apresentaram discordância significativa (G. calculado $=17,45$ e G. crítico $=9,49$ ). Verificou-se uma tendência de aumento da soropositividade com o evoluir da idade, porém sem estatística significativa $(p=0,416)$. A cultura apresentou $42 \%$ de concordância com o padrão definido e sensibilidade, especificidade, valor preditivo positivo e negativo de 77, 100, 100 e 35\%, respectivamente; Kappa: 0,42 ( $<<0,000001)$. 0 exame histológico concordou com o padrão escolhido em 93,0\%, Kappa: 0,93 ( $p<0,000001$ ). $\mathrm{O}$ exame direto apresentou concordância de 74\%, Kappa: 0,74 ( $\mathrm{p}<0,000001$ ) e 90, 100, 100 e $64 \%$ de sensibilidade, especificidade, VPP e VPN, respectivamente. O teste da urease, por sua vez, apresentou concordância de $74 \%$, Kappa: 0,74 ( $p<0,000001)$; sensibilidade, especificidade, VPP e VPN respectivamente, de $93,100,100$ e $64 \%$ e o teste de ELISA concordou em $38 \%$ da concordância máxima esperada, apresentando índice Kappa de 0,38 ( $p<0,000003$ ). A sensibilidade foi de $91 \%$, especificidade de years of age, corresponding to $37 / 125$ (29.6\%), and the lowest concentration was observed among the elderly (between 55 and 80 years of age), where the prevalence was $12 / 125$ (9.6\%). Nevertheless, statistical analysis did not display any significant difference between the number of positives from the two groups $(p=0.356)$. Among the positive patients, 45/125 (36\%) were males, whereas $80 / 125$ (64\%) were females. No statistically significant difference was observed in the distribution of the infection according to sex $(p=0.275)$, race (black or non-black $p=0.305)$, marital status (0.943) or profession $(p=0.788)$, even although a remarkably high incidence of positive cases was observed among public employees (68.8\%).

The most common complains of the patients were stomach ache and heartburn and the most common endoscopic finding was common gastritis, followed by gastric ulcers. Statistical analysis did not reveal any significant association between $H$. pylori infection and the above pathologies. Chronic Gastritis and Active Chronic Gastritis were the most common findings, with 43.2 and $33.4 \%$ of the positives, respectively, and there was a significant association between the histopathological alterations and the presence of $H$. pylori $(p=0.000083)$.

The five diagnostic methods tested showed significant discordance degree ( $G$ "calculated" = 17.45 and $G$ "critical" $=9.49$ ), with the following levels of positive rates: $82.3 \%$ (urease), $80.1 \%$ (stained smear), $69.5 \%$ (culturing), $87.2 \%$ (histology) and $86.5 \%$ (ELISA). An increase in the seropositivity was observed in relation to increased age, even though this phenomenon was not statistically significant $(p=0.416)$. Culturing was $42 \%$ in accordance with the gold standard, with sensitivity, specificity, positive and negative predictive values (PPV and NPV) of 77, 100, 100 and $35 \%$, respectively, Kappa: 0.42 ( $p<0.000001)$. The histological examination was in accordance with the specified standard with 93\%, Kappa: $0.93(p<0.000001)$. The direct examination of stained smears had an accordance rate of $74 \%$, Kappa: 0.74 ( $p<0.000001)$ with 90, 100, 100 and $64 \%$ for sensitivity, specificity, PPV and NVP, respectively. The urease test had an accordance rate of $74 \%$, Kappa: $0.74(p<0.000001)$, with rates of sensitivity, specificity, PPV and NVP of 93, 100, 100 and $64 \%$. Finally, the ELISA test showed an accordance rate of $38 \%(p<0.000003)$. The sensitivity was around $91 \%$, with $50 \%$ for specificity, $93 \%$ for PPV and $42 \%$ for NVP. 
$50 \%$, VPP de $93 \%$ e VPN de $42 \%$. A associação de queixa clínica (pirose e epigastralgia) com vários pontos de cortes sorológicos, comparados com o padrão apresentou o seguinte perfil: diminuição da sensibilidade, gradativamente, com o aumento do ponto de corte, de $82,4 \%$ a $27,2 \%$ no corte de $60 \mathrm{U} / \mathrm{ml}$; aumento da especificidade de $56,2 \%$ no corte de $10 \mathrm{U} / \mathrm{ml}$ a $93,7 \%$ no corte de $40 \mathrm{U} / \mathrm{ml}$. Não houve alteração nos valores preditivos positivos (máximo de $98,1 \%$ no corte de $60 \mathrm{U} / \mathrm{ml}$ e mínimo de $93,6 \%$ no de $10 \mathrm{U} / \mathrm{ml}$ ). Houve decréscimo dos valores preditivos negativos, de $29,0 \%$ no corte de $10 \mathrm{U} / \mathrm{ml}$ a $14,1 \%$ no de $60 \mathrm{U} / \mathrm{ml}$. O melhor resultado pelos diversos pontos de corte foi obtido com $20 \mathrm{U} / \mathrm{ml}$. O perfil dos demais testes invasivos está em concordância com a literatura. A sorologia apresentou sensibilidade e valor preditivo positivo bons, tanto com o "cut-off" de $10 \mathrm{U} / \mathrm{ml}$ preconizado pelo fabricante do kit, quanto no corte de $20 \mathrm{U} / \mathrm{ml}$ em associação com queixa clínica.
Association between the patients' complaints about the clinical symptoms (pirose and epigastralgia) and several points of serological cutoff showed the following profile when compared to the gold standard: a decrease in the cutoff caused the sensitivity to show a gradual decrease from $82.4 \%$ (cutoff $=10 \mathrm{U} / \mathrm{ml}$ to $27.2 \%$ (cutoff $=60 \mathrm{U} / \mathrm{ml}$ ). Specificity increased from $56.2 \%$ (cutoff $=10 \mathrm{U} / \mathrm{ml}$ ) to $93.7 \%$ (cutoff $=60$ $\mathrm{U} / \mathrm{ml}$ ). No significant alteration was observed in PPV $(\max =98.1 \%$ with a cutoff $=60 \mathrm{U} / \mathrm{ml}$ and $\min =93.6 \%$ with a cutoff $=10 \mathrm{U} / \mathrm{ml})$. There was a decrease in NPV , from $29 \%$ (cutoff $=10 \mathrm{U} / \mathrm{ml}$ to $14,1 \%$ (cutoff $=60 \mathrm{U} / \mathrm{ml}$. The best results for the many tested cutoff points was obtained with a cutoff $=20 \mathrm{U} / \mathrm{ml}$. The profile of the remaining invasive tests in accordance with what is observed in the literature. Serology showed good values for sensitivity and PPV, both at a cutoff $=10 \mathrm{U} / \mathrm{ml}$ (recommended by the kit's manufacturer) as well as at a cutoff $+20 \mathrm{U} / \mathrm{ml}$, in association with the patients' complaints.

José de Macêdo Bezerra

Tese apresentada à Escola Paulista de Medicina da

Universidade Federal de São Paulo, para

obtenção do Título de Doutor.

São Paulo, SP, Brasil, 1997. 